(Received January 20, 1988)

\title{
APPLICATION OF THE FOAM DYEING METHOD TO DYEING OF WOOLEN FABRIC WITH ACID DYES ${ }^{* 1}$
}

\author{
By Masashi Kobayashi and Motoi Minagawa \\ (Faculty of Science of Living, Osaka City University, \\ Sugimoto, Sumiyoshi-ku, Osaka, 558 Japan)
}

\begin{abstract}
The foam dyeing apparatus has been developed for the saving of water and/or energy-saving in dyeing processes, the reduction of contamination of natural environment by the waste fluid, and the prevention of injury or damage of dyeing substrates. Consequently, the physical function that damages dyeing substrate is reduced, and extremely low bath ratio is realized, further the energy needed in heating up is diminished.

In this report, the application of the foam dyeing method to the woolen fabric-acid dye system, and the investigation of the dyeing property, the blow ratio, the foaming property of the bulk liquid or the foam stability, and the dye content of the foam film were carried out, and following results have been obtained:

1) A dye uptake of fabric was increased with the reduction of the bath ratio. This might be considered that a dye concentration in the bulk liquid is more concentrated as a results of decrease of bath ratio.

2) The good dyeing property was brought by the use of the foaming agent characterized by its rather hydrophobic property. But the cloud point of the bulk liquid must be taken into consideration from the viewpoint of the foaming property and foam stability.

3) The dye content of the foam film was slightly lower than that of the bulk liquid, though the correction of the dye content could be simply done by the addition of dye to the bulk liquid conforming to a linear calibration curve.

4) In the foam dyeing method, a foam was formed continuously and rose into the cylindrical dye-bath, the dyeing substrate was initially wetted by the foam, and dye molecule transported by the foam film was adsorbed on the substrate-liquid interface, and it was uniformly diffused into the substrate under the appropriate dyeing condition; $3 \mathrm{l} / \mathrm{min}$ of the air flow rate, 2.0 to $2.5 \%$ region of acetic acid content, at $80^{\circ} \mathrm{C}$, and for $30 \mathrm{~min}$.
\end{abstract}

\section{Introduction}

The modern clothing is of importance not only from the viewpoint of controlling the human surrounding environments but also as the means of expressing the fashion including the life style or as the status symbol. Therefore, the clothing has been diversified by a variety of consumers' demands and the manufacturing processes of clothing have been complicated more and more.

On the other hand, the rationalization of each dyeing process has been urgently required to cope

"Studies on the foam dyeing (Part 3) with the business depression of textile industry and to comply with the energy-, resources-, or water-saving, the conservation of the natural environment, and so forth. ${ }^{1)}$ The reduction of the dyeing time or the dyeing bath ratio has been derived by a number of new dyeing processes or methods on condition without quality deterioration. Since 1971, the batch dyeing that utilizes bubbles and replaces the great part of water with the air, has been published. But they yet have problems as the stability of the bath mainly consisted of bubbles, or the alteration of the humidity. ${ }^{2-4)}$ 
Then, authors have developed the foam dyeing apparatus in expectation of the trend toward the small lot production to satisfy various needs of consumers, aiming at the water- or energy-saving in dyeing process, the reduction of contamination of natural environment by the waste fluid, the prevention of injury or damage of dyeing substrates, and the improvement of color fastness. The foam dyeing method is different from conventional batch dyeing methods including the bubble (in which the blow ratio is in the range of 10 to 60 ) dyeing, in respect of using foams having blow ratio of 200 to 300 region. Consequently, the physical function that damages dyeing substrate is reduced, and extremely lower bath ratio is realized, further the energy needed in heating up is diminished. ${ }^{5)}$ Simultaneously with the development of the foam dyeing apparatus, elucidation of the dyeing mechanism and investigation of the dynamic characteristics of foam film in the foam dyeing method are planned in this study.

In this report, the examination of the applicability of the foam dyeing method to the woolen fabric-acid dye system, and the investigation of the dyeing property, the blow ratio, the foaming property of the bulk liquid or the foam stability of the bulk liquid, and of the dye content of the foam film were carried out and results were compared with those of the dip dyeing method.

\section{Experimental}

\subsection{Materials}

A woolen fabric provided specially for dyeing tests by courtesy of Nakao Filter Co., Ltd. was employed as a dyeing substrate in experiments. It was retreated, in order to remove impurities and to unify the surface of the fabric, by double soaking in $5 \mathrm{~g} / l$ of sodium carbonate solution at 50 to $60^{\circ} \mathrm{C}$ for 30 minutes followed by rinsing with distilled water, and was air-dried at room temperature. It had profiles of $0.23 \mathrm{~mm}$ thickness and 30 warps and wefts per $\mathrm{cm}$ in yarn count.

Acid dyes used are shown in Fig. 1. They were commercially produced by Sumitomo Chemical Co., Ltd. and used without further purification. Each of them has different typical structures, namely monoazo, disazo, anthraquinone, triarylmethane, xanthene, and azine group.
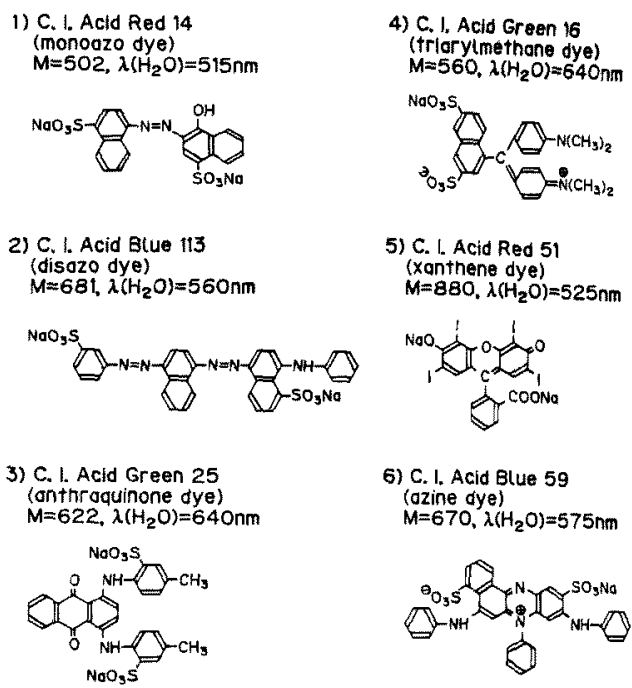

Fig. 1 Dyes used in the foam dyeing method.

Nonionic surfactants used as foaming agent in the foam dyeing method are shown in Table 1 with their molecular weight (M) and hydrophile-liphophile balance (HLB). Polyoxyethylene (P:15) oleyl ether (OPE-15) was mainly used. These were selected by considering their effective properties for the dyeing, the foaming property or the foam stability. Further, the cloud point (CP) and the biodegradability were also taken into consideration.

Further, anionic surfactants were also used as foaming agent. Generally they are characterized by their affinities for woolen fabrics while nonionic ones for acid dyes. ${ }^{6}$

\subsection{Method}

\subsubsection{Dyeing condition}

The woolen fabric was dyed in the foam dyeing apparatus (Fig. 2) fundamentally under the following conditions:
dye concentration:
$2.5 \%$ o.w.f
surfactant concentration:
$0.5 \%$
acetic acid concentration: $2.5 \%$ o.w.f
$\mathrm{pH}: 3.3,80^{\circ} \mathrm{C}, 30 \mathrm{~min}$, air flow rate: $3 \mathrm{l} / \mathrm{min}$
The model test of dip dyeing to compare with the foam dyeing method was also put to trial under the same condition of the foam dyeing except the use of a 100-ml Erlenmeyer flask and Taiyo Incubator $\mathrm{M}-300^{\mathrm{D}}$ at 100 s.p.m. 
Table 1 Surfactants used as foaming agents in the foam dyeing method.

\begin{tabular}{|c|c|c|c|c|}
\hline foaming agents & & M & HLB & $\begin{array}{l}\mathrm{CP} \\
\left({ }^{\circ} \mathrm{C}\right)\end{array}$ \\
\hline \multicolumn{5}{|l|}{ (nonionic surfactants) } \\
\hline Polyoxyethylene (P:15) lauryl ether & [LPE-15] & 846 & 14.1 & 96 \\
\hline Polyoxyethylene $(P: 20)$ lauryl ether & {$[\mathrm{LPE}-20]$} & 1066 & 15.3 & 98 \\
\hline Polyoxyethylene (P:47) lauryl ether & {$[$ LPE-47] } & 2257 & 16.3 & $>98$ \\
\hline Polyoxyethylene (P:15) stearyl ether & {$[\mathrm{SPE}-15]$} & 930 & 12.2 & 90 \\
\hline $\begin{array}{l}\text { Polyoxyethylene (P:15) oleyl ether } \\
\text { (anionic surfactants) }\end{array}$ & {$[\mathrm{OPE}-15]$} & 928 & 12.2 & 90 \\
\hline Sodium Dodecyl Sulfate & [S D S ] & 288 & & \\
\hline Dodecyl Benzene Surfonate & [D B S] & 348 & & \\
\hline$\alpha$-Olefin Sulfonate & {$[\mathrm{AOS}]$} & 357 & & \\
\hline
\end{tabular}

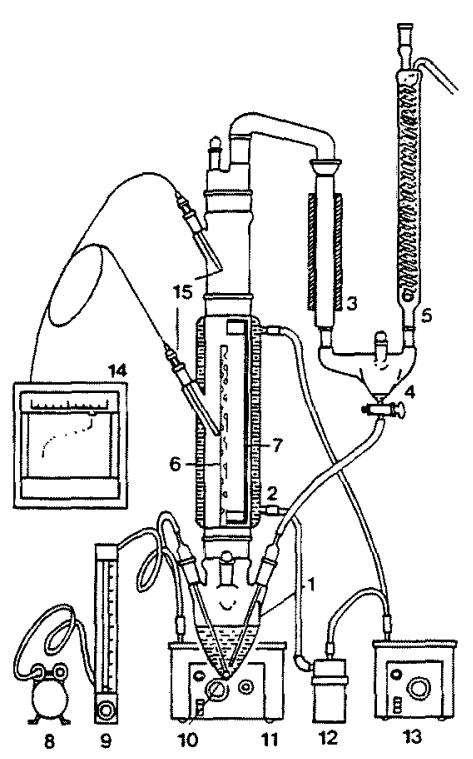

Fig. 2 The foam dyeing apparatus.

1: flask for reserving bulk liquid, 2: glass tubing with water jacket, 3 : heating foam breaker, 4: flask for reserving residual liquid, 5: reflux condenser, 6: center tube, 7: woolen fabric, 8: air pump, 9: air flow meter, 10: glass ball filter, 11: oil bath, 12: water pump, 13: water bath, 14: recording thermometer, 15 : thermocouples

\subsubsection{Determination of dye uptake of woolen fabric}

The concentration of dye on woolen fabric was determined spectrophotometrically from the absorbances of the extracts from the fabric. $25 \%$ of pyridine aqueous solution was used as the extracting medium. One of main objects of this report is to clarify the applicability of foam to practical dyeing, therefore, authors adopted "milligram per gram-fabric" as the commercially useful unit of dye uptake.

\subsubsection{The foam dyeing apparatus}

As shown in Fig. 2, the foam dyeing apparatus used in this study consists of five main parts; namely a flask for reserving the bulk liquid (1), a glass tubing with water jacket as a cylindrical dye-bath (2), a heating foam-breaker (3), a flask for reserving the residual liquid (4), and a reflux condenser (5). The reserving flasks for the bulk liquid and for the residual liquid are connected to a thin tubing in order to circulate the dyeing liquid. It has also an air pump (7) for blowing air through the bulk liquid, an air flow meter (8) with controlling needle valve, a glass ball filter (9) for dispersing air, an oil bath (10) for heating and maintenance of a constant temperature of the bulk liquid, and a recording thermometer (13) with thermocouples (14). Further the center tube with foam effluent holes is set in the dyeing cylindrical dye-bath of the apparatus to prevent uneven dyeing caused by the foam drainage, and the holes are $6.5 \mathrm{~mm}$ in diameter, the average opening ratio is $10 \%$, and the distribution of the opening area of them are exponentially increased at the upper part from the results shown in Fig. 3 and Fig. 4.

\subsubsection{The foam dyeing method}

A dyeing operation in the foam dyeing method is carried out as follows. At first, the bulk liquid is heated up to a desired temperature and air is blown into the bulk liquid through the glass ball 


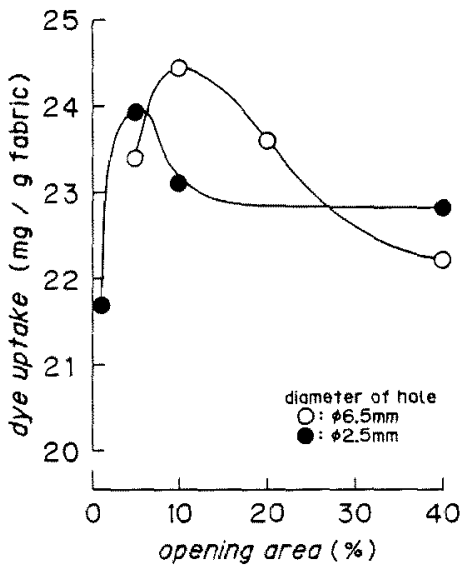

Fig. 3 Effect of opening area and diameter of hole in the center tube on dye uptake of acid dye for woolen fabric. C. I. Acid Blue 113: 2.5\% o.w.f., OPE-15: $0.5 \%$, acetic acid: $2.5 \%$ o.w.f.
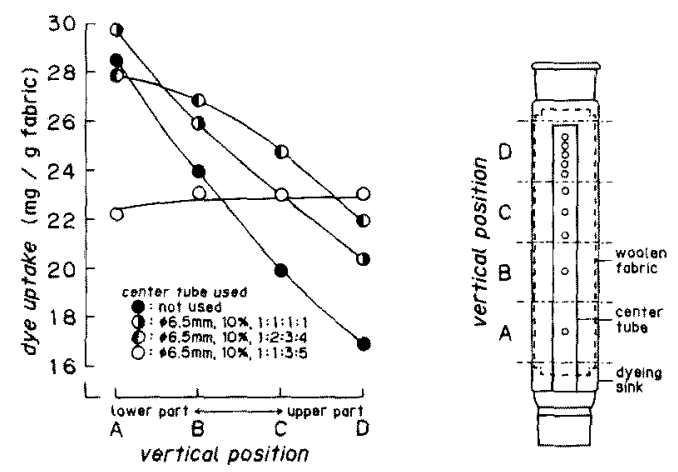

Fig. 4 Effect of distribution of opening area on the dyeability of acid dye for woolen fabric at each vertical position. C. I. Acid Blue 113: 2.5\% o.w.f., OPE-15: 0.5\%, acetic acid: $2.5 \%$ o.w.f.

filter and dispersed entirely. The foam, containing dye in its foam film, is formed continuously and rises into the glass tubing. A dyeing substrate is initially wetted and dye molecule transported by the foam is adsorbed on the substrate-liquid interface, and it is uniformly diffused into the substrate under a given dyeing condition. The foam overflowing from the cylindrical dye-bath is led to the heating foam-breaker and defoamed. The residual dyeing liquid is returned to the flask of the bulk liquid through the thin glass tubing for circulation.

\subsubsection{Measurement of the dye content in foam film and blow ratio}

The dye content in the foam film was measured spectrophotometrically from the absorbance of the dyeing liquid that once formed the foam and spontaneously broke in the polyethylene bag for collecting the foam. The bag was set instead of the flask for residual liquid.

The blow ratio was estimated from the quantity of the dyeing liquid collected in the bag, the time for collection and the air flow rate. When these values were measured, the dyeing operation was done without the dyeing substrate.

\subsubsection{Quantification of the foaming property of the bulk liquid and foam stability}

The foaming property of the bulk liquid and the foam stability have been quantified by the method of Ross and Miles, in which $200 \mathrm{ml}$ the test solution is poured from $900 \mathrm{~mm}$ height in $30 \mathrm{sec}$ to the surface of $50 \mathrm{ml}$ solution that has the same composition as the test solution. The foam height at the end of pouring is regarded as the foaming property and that $5 \mathrm{~min}$ after pouring is as the foam stability. ${ }^{\text {? }}$ )

\section{Results and Discussion}

\subsection{Effect of bath ratio}

The foam dyeing apparatus used in the experiment needs at least $40 \mathrm{ml}$ of bulk liquid to fill up with the foam, to continuously generate and circulate the foam. Further $1 \mathrm{~g}$ of woolen fabric absorbs about $1 \mathrm{ml}$ of dyeing liquid in the dyeing process. So the bath ratio of the foam dyeing method has to be decided under taking them into consideration. Then authors had made an experiment, to test the effect of bath ratio, with a fabric ranging from $1: 3$ to $1: 25$ in bath ratio while the volume of the bulk liquid was fixed to $50 \mathrm{ml}$ and the dye concentration on the weight of fabric was $2.5 \%$. A dye uptake on fabric was increased with the reduction of the bath ratio as shown in Fig. 5 . This might be considered that the dye concentration in the bulk liquid is more concentrated as a result of decrease of bath ratio. So it is expected that the dyeing method like foam dyeing method, which aims the reduction of bath ratio, increases the dye uptake of the substrates in relation to the use of concentrated dye solution. 


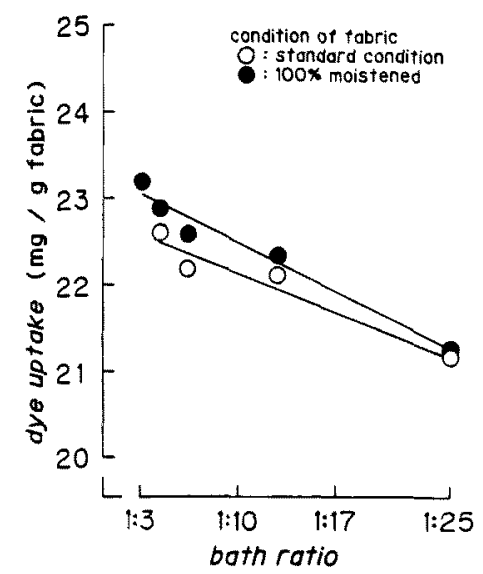

Fig. 5 Effect of bath ratio on dye uptake of woolen fabric for C. I. Acid Blue 113. C. I. Acid Blue 113: 2.5\% o.w.f., OPE-15: $0.5 \%$, acetic acid: $0.1 \%$.

Further the effect of pre-moistening was examined, that is to say the test fabric was moistened to $100 \%$ of water content before dyeing operation. Pre-moistening enlarged the dye uptake on fabric more remarkably at lower bath ratio. The effect of pre-moistening was negligible at bath ratio of 1:25.

In the following experiments, we adopted the bath ratio of $1: 25$ to make the comparison between the foam dyeing method and the dip dyeing method. This bath ratio is of lowest limit to perform a dip dyeing.

\subsection{Effect of air flow rate}

The air flow rate in the range of 1 to 5 liters per minute can be applied to the foam dyeing method under consideration of the shape and the inner volume of the cylindrical dye-bath, and the foam breaking ability of the foam dyeing apparatus. Fig. 6 shows that the dye uptake on fabric increased with the increase of air flow rate within $3 \mathrm{l} / \mathrm{min}$ and inversely decreased at higher rate than $3 \mathrm{l} / \mathrm{min}$.

To reveal the cause of this phenomenon, the effect of air flow rate on the dye content in the foam film and the blow ratio were investigated and the results are shown in Table 2. The dye content in the foam film increased with the increase of air flow rate within $3 \mathrm{l} / \mathrm{min}$ and reached equilibrium. The blow ratio decreased with the air flow rate within $3 \mathrm{l} / \mathrm{min}$, and increased at

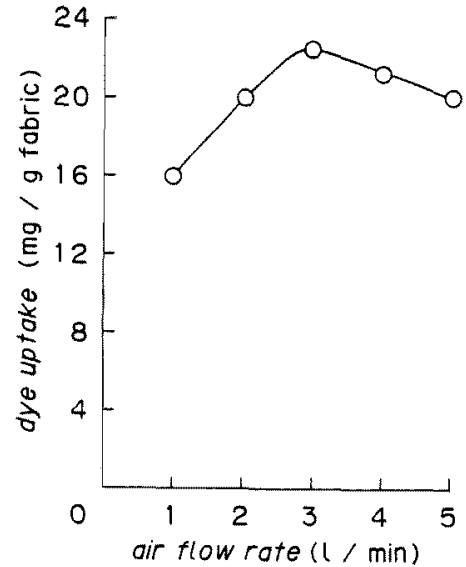

Fig. 6 Effect of air flow rate on dye uptake of woolen fabric for C. I. Acid Blue 113. C. I. Acid Blue 113: 2.5\% o.w.f., OPE-15: $0.5 \%$, acetic acid: $2.5 \%$ o.w.f.

Table 2 Effect of air flow rate on dye content of foam film and blow ratio at $80^{\circ} \mathrm{C}$. C. I. Acid Blue 113: 0.1\%, OPE-15: 0.5\%, acetic acid: $0.1 \%$.

\begin{tabular}{ccc}
\hline $\begin{array}{c}\text { air flow rate } \\
(l / \mathrm{min})\end{array}$ & $\begin{array}{c}\text { dye content } \\
\text { of foam film } \\
(\%)\end{array}$ & blow ratio \\
\hline 1 & 0.089 & 270 \\
2 & 0.094 & 210 \\
3 & 0.096 & 160 \\
4 & 0.096 & 220 \\
5 & 0.096 & 270 \\
\hline
\end{tabular}

higher rate than $3 \mathrm{l} / \mathrm{min}$. Blow ratio indicates the thickness of the foam film if the diameter of the bubbles in foam is assumed to be constant as this method. So the thickness of the foam film in the foam dyeing method can be regarded to increase to a particular air flow rate because of the rate of the foam rising is increased more swiftly than the drainage, and to decrease at higher rate than that because of the instability of the foam generation.

The air flow rate has intense effects on the dyeing property in connection with the foam volume and the foam rising rate and so forth. ${ }^{8}$ ) So the air flow rate of $3 \mathrm{l} / \mathrm{min}$ is most appropriate to produce the good dyeing property and the uniformity for this foam dyeing apparatus. 


\subsection{Effect of varieties of foaming agents and of their concentration}

Effects of various surfactants used as foaming agents on the dyeing property indicated by the value of dye on fabric are shown in Table 3. Anionic surfactants characterized by their affinity for woolen fabrics manifested fairly small values of dye on fabric in comparison with nonionic ones having affinity for acid dyes.

Comparison among nonionic ones, the longer alkyl chain and shorter ethylene oxide chain exhibited larger value of dye on fabric. Further the introduction of unsaturated group into alkyl

Table 3 Effect of foaming agents on dye uptake of woolen fabric. Foaming agent: $0.5 \%$, C. I. Acid Blue 113: 2.5\% o.w.f., acetic acid: $2.5 \%$ o.w.f.

\begin{tabular}{cc}
\hline foaming agents & $\begin{array}{c}\text { dye uptake } \\
\text { (mg/g fabric) }\end{array}$ \\
\hline (nonionic surfactants) & \\
LPE-15 & 21.3 \\
LPE-20 & 21.1 \\
LPE-47 & 20.8 \\
SPE-15 & 22.0 \\
OPE-15 & 22.5 \\
(anionic surfactants) & \\
S D S & 6.5 \\
D B S & 4.6 \\
A O S & 2.3 \\
\hline
\end{tabular}

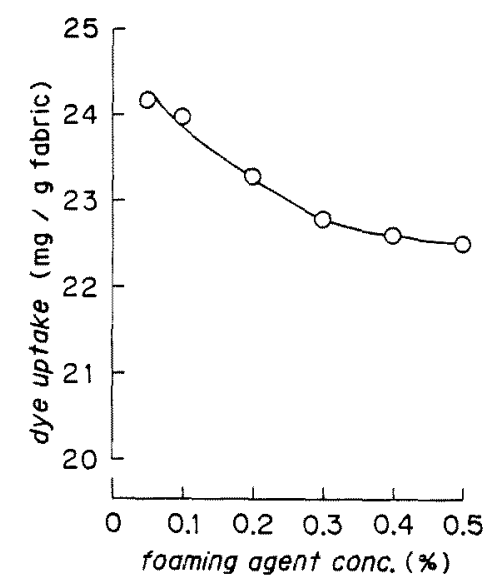

Fig. 7 Effect of concentration of foaming agent (OPE-15) on dye uptake of woolen fabric for C. I. Acid Blue 113. C. I. Acid Blue 113: 2.5 o.w.f., acetic acid: $2.5 \%$ o.w.f. chain also enlarged the value. Generally, the good dyeing property was brought by the use of the foaming agent characterized by its rather hydrophobic property. However, this characteristic lowers the cloud point of the bulk liquid. The foaming property and the foam stability are extremely reduced at the temperature higher than the cloud point.

Fig. 7 shows the effect of the concentration of OPE-15 on dyeing property. The increase of the concentration of foaming agent decreased the value of dye on fabric without abruptness and the reduction more diminished in the region more than $0.3 \%$ of foaming agent concentration.

The effect of concentration of foaming agent on blow ratio, foaming property of bulk liquid and foam stability were also investigated and shown in Table 4 . The blow ratio decreased with the increase of the concentration of foaming agent. It suggests that the thickness of the foam film became larger, while foaming property of bulk liquid and foam stability are increased.

Table 4 Effect of foaming agent (OPE-15) concentration on blow ratio, foaming property of bulk liquid, and foam stability at $80^{\circ} \mathrm{C}$. C. I. Acid Blue 113: $0.1 \%$, acetic acid: $0.1 \%$.

\begin{tabular}{cccc}
\hline $\begin{array}{c}\text { foaming agent } \\
\text { concentration } \\
(\%)\end{array}$ & blow ratio & \multicolumn{2}{c}{ foam height $(\mathrm{mm})$} \\
\cline { 3 - 4 } & & $0 \mathrm{~min}$ & $5 \mathrm{~min}$ \\
\hline 0.05 & 250 & 90 & 10 \\
0.10 & 220 & 100 & 10 \\
0.20 & 200 & 100 & 11 \\
0.30 & 180 & 110 & 11 \\
0.40 & 170 & 110 & 11 \\
0.50 & 160 & 110 & 11 \\
\hline
\end{tabular}

\subsection{Effects of acid dyes and their concentration}

Dyeing properties arising from various acid dyes were shown in Fig. 8. These figures show not only the values of dye on fabric obtained by the foam dyeing method but also the values acquired by dip dyeing method, in which the condition free from surfactants was applicable. And the maximum values of dye on fabric were confirmed in the absence of surfactant. The comparison between the values of dip dyeing proved that the addition of surfactant more strongly affected the 




Fig. 8 Dye uptake of various acid dyes. Dye concentration: $2.5 \%$ o.w.f., OPE-15: $0.5 \%$, acetic acid: $2.5 \%$ o.w.f.

values of dye uptake on fabric of C. I. Acid Red 14 and C. I. Acid Blue 113 in comparison with others.

In the comparison between the values of foam dyeing and those of dip dyeing, the values of foam dyeing were smaller than that of dip dyeing. The dye content of foam film was also investigated and shown in Table 5. Dye content of foam film for C. I. Acid Red 51 and for C. I. Acid Blue 59 were lower and the difference of the values of dye on fabric between foam dyeing and dip dyeing for them were higher as shown in Fig. 8. So the difference of dyeing properties between foam dyeing and dip dyeing is mainly caused by the reduction of dye content in the foaming process.

Further the relationships between dye contents of bulk liquid and foam film were shown in Fig. 9 for C.I. Acid Blue 113, as a representative of large value, and for C. I. Acid Red 51, as that of small one. Both of them exhibited proportional, and the regression lines have the slopes of 0.96 for C. I. Acid Blue 113 and 0.84 for C. I. Acid Red 51. The correction of the dye content of foam film was tried by the addition of the dye conforming to the calibration chart, viz., Fig. 9. As shown in Fig. 10 the dye uptake on a fabric
Table 5 Effect of acid dyes on dye content of foam film, and dye uptake of woolen fabric at $80^{\circ} \mathrm{C}$. Acid Dye: $0.1 \%=2.5 \%$ o.w.f.), OPE-15: 0.5\%, acetic acid: $0.1 \%$ $(=2.5 \%$ o.w.f. $)$

\begin{tabular}{lcc}
\hline \multicolumn{1}{c}{ acid dye } & $\begin{array}{c}\text { dye content } \\
\text { of foam film } \\
(\%)\end{array}$ & $\begin{array}{c}\text { dye uptaka } \\
\text { (mg/g fabric) }\end{array}$ \\
\hline C. I. Acid Red 14 & 0.096 & 23.5 \\
C. I. Acid Blue 113 & 0.096 & 22.5 \\
C. I. Acid Green 25 & 0.095 & 22.5 \\
C. I. Acid Green 16 & 0.090 & 21.7 \\
C. I. Acid Red 52 & 0.084 & 20.0 \\
C. I. Acid Blue 59 & 0.087 & 20.0 \\
\hline
\end{tabular}

obtained by the correction were similar to that of a dip dyeing.

On the other hand, the effect of concentration of C. I. Acid Blue 113 on blow ratio, foaming property of bulk liquid, and foam stability were also investigated and shown in Table 6. Blow ratio is decreased inversely as the concentration of acid dye. It suggested that the thickness of the foam film more thickened, and foaming property of bulk liquid and foam stability were decreased with increase of concentration of foaming agents.

\subsection{Effect of acetic acid concentration}

Fig. 11 shows that dye on fabric abruptly increased with addition of acetic acid through a concentration of $2.5 \%$ o.w.f., although it showed somewhat constant value above the concentration of $2.5 \%$ o.w.f.

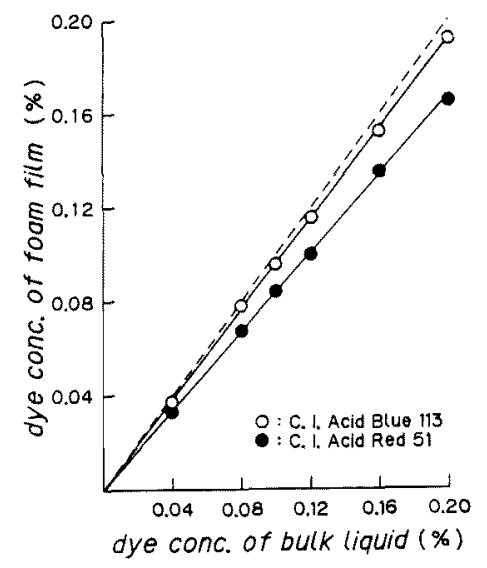

Fig. 9 Relationships between dye contents of bulk liquid and of foam film. OPE-15: $0.5 \%$, acetic acid: $2.5 \%$ o.w.f. 
a) C. I. Acid Blue 113

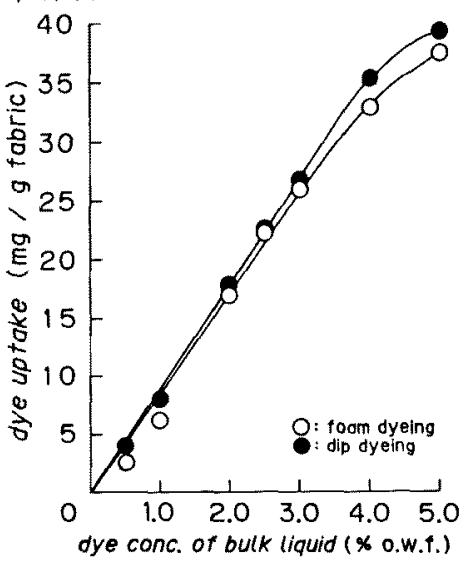

b) C. I. Acid Red 51

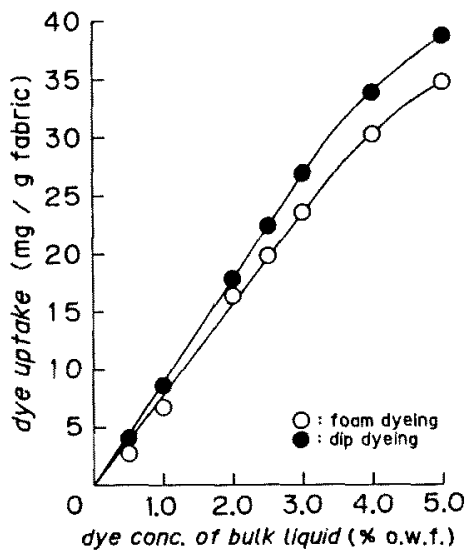



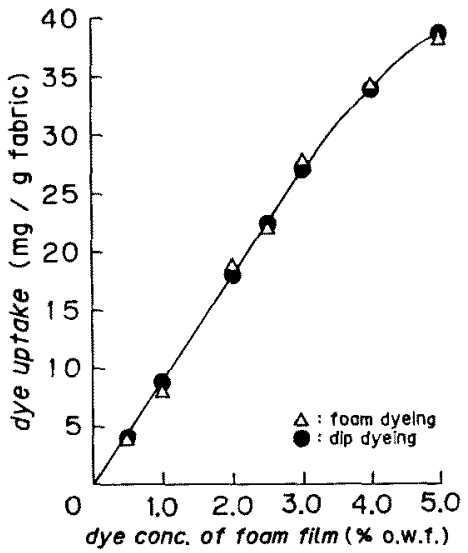

Fig. 10 Effect of concentration of acid dyes on dye uptake of woolen fabric. OPE-15: $0.5 \%$, acetic acid: $2.5 \%$ o.w.f.

Table 6 Effect of acid dye (C. I. Acid Blue 113) content on blow ratio, foaming property of bulk liquid, and foam stability at $80^{\circ} \mathrm{C}$. OPE $15: 0.5 \%$, acetic acid: $0.1 \%$.

\begin{tabular}{lccc}
\hline $\begin{array}{c}\text { acid dye } \\
\text { content } \\
(\%)\end{array}$ & blow ratio & \multicolumn{2}{c}{ foam height $(\mathrm{mm})$} \\
\cline { 3 - 4 } & & $0 \mathrm{~min}$ & $5 \mathrm{~min}$ \\
\hline 0 & 180 & 230 & 11 \\
0.02 & 170 & 210 & 16 \\
0.04 & 170 & 150 & 12 \\
0.08 & 160 & 120 & 12 \\
0.10 & 160 & 110 & 11 \\
0.12 & 160 & 110 & 11 \\
0.16 & 150 & 110 & 11 \\
0.20 & 150 & 100 & 11 \\
\hline
\end{tabular}

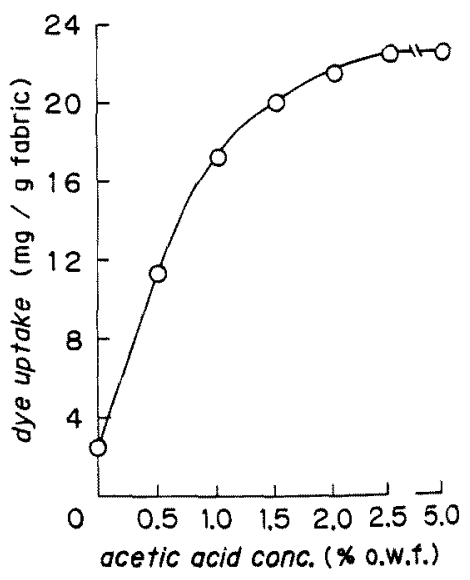

Fig. 11 Effect of concentration of acetic acid on dye uptake of woolen fabric for C. I. Acid Blue 113. C. I. Acid Blue 113: $2.5 \%$ o.w.f., OPE-15: $0.5 \%$ 
Dye content of foam film was reduced by the addition of acetic acid, but the dependence on the concentration of that values could not be appreciated as shown in Table 7 . The foaming property of bulk liquid was lowered with the increase of the concentration of acetic acid while foam stability of that was constant. These phenomena of the reduction of dye content of foam film and of foaming property, will decrease the dyeing property of woolen fabric. Though the addition of acetic acid elevated the dyeing property because the acid dyes are adsorbed on woolen substrate mainly by the ionic bonding under the isoelectric point of woolen substrate. ${ }^{9)}$ And it has been admitted that the dye adsorbed on woolen fabric by means of ionic bonding has excellent fastness property.

Table 7 Effect of acetic acid content on dye content of foam film, blow ratio, foaming property of bulk liquid, and foam stability at $80^{\circ} \mathrm{C}$. C. I. Acid Blue 113 : $0.1 \%$, OPE-15: $0.5 \%$.

\begin{tabular}{lcccc}
\hline \multirow{2}{*}{$\begin{array}{c}\text { acetic acid } \\
\text { content } \\
(\%)\end{array}$} & $\begin{array}{c}\text { dye content } \\
\text { of foam film } \\
(\%)\end{array}$ & blow ratio & & \multicolumn{2}{c}{ foam height (mm) } \\
\cline { 5 - 6 } & $(\%$ min & 5 min \\
\hline 0 & 0.097 & 140 & 180 & 11 \\
0.02 & 0.096 & 160 & 170 & 11 \\
0.04 & 0.096 & 160 & 140 & 11 \\
0.06 & 0.096 & 160 & 120 & 11 \\
0.08 & 0.096 & 160 & 110 & 11 \\
0.10 & 0.096 & 160 & 110 & 11 \\
0.20 & 0.096 & 160 & 110 & 11 \\
\hline
\end{tabular}

\subsection{Effect of temperature and dyeing time}

The more uptake of dye on a fabric was obtained at the higher temperature as shown in Fig. 12. Rise in temperature causes reduction of dye content of foam film, foaming property of bulk liquid, and foam stability as shown in Table 8 . These reduction might affect the dyeing property, but could not be pointed out because the rise in temperature substantially increases the diffusion rate of acid dyes. ${ }^{10)}$

Fig. 13 shows the increases of dye on fabric with elapse of dyeing time obtained by both dyeing methods. It was saturated in $c a .30 \mathrm{~min}$. The dye uptake on fabric obtained by a foam dyeing indicated smaller value in comparison with

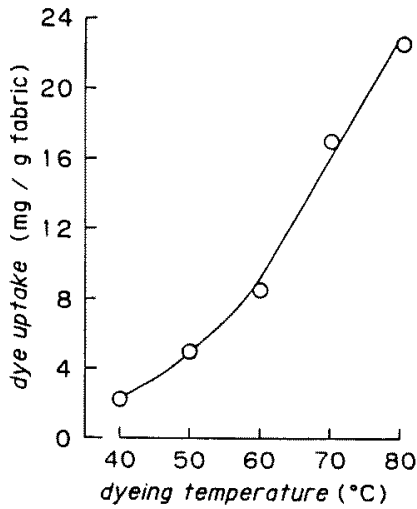

Fig. 12 Effect of temperature on dye uptake of woolen fabric for C. I. Acid Blue 113. C. I. Acid Blue 113: 2.5\% o.w.f., OPE-15: $0.5 \%$, acetic acid: $2.5 \%$ o.w.f.

Table 8 Effect of temperature on dye content of foam film, blow ratio, foaming property of bulk liquid, and foam stability at $80^{\circ} \mathrm{C}$. C. I. Acid Blue 113: $0.1 \%$, OPE- $15: 0.5 \%$, acetic acid: $0.1 \%$.

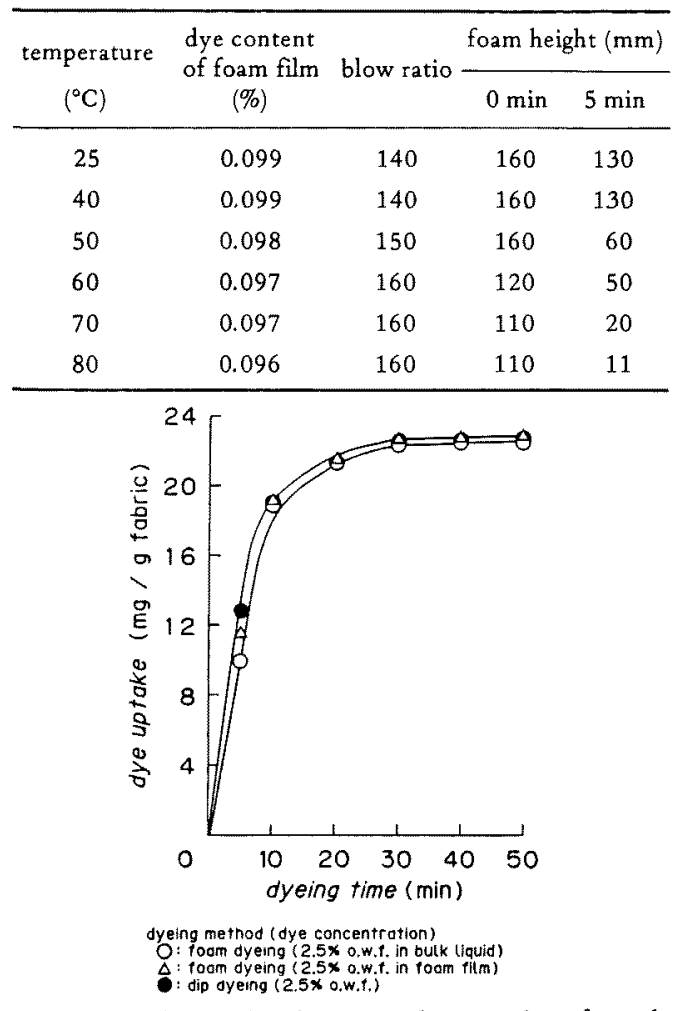

Fig. 13 Relationship between dye uptake of woolen fabric and dyeing time. Dye: C. I. Acid Blue 113, OPE-15: 0.5\%, acetic acid: $2.5 \%$ o.w.f. 
that of dip dyeing. Here, the correction of dye concentration of foam film was tried again with success.

\section{Conclusion}

1) The dye uptake on fabric was increased with the reduction of the bath ratio. This might be considered that the dye concentration in the bulk liquid is more concentrated as a results of decrease of bath ratio.

2) The good dyeing property was brought by the use of the foaming agent characterized by its rather hydrophobic property. But the cloud point of the bulk liquid must be taken into consideration from the viewpoint of the foaming property and foam stability.

3) The dye content of the foam film was slightly lower than that of the bulk liquid, though the correction of the dye content could be simply done by the addition of dye to the bulk liquid conforming to the linear calibration curve.

4) In the foam dyeing method, a foam was formed continuously and rose into the cylindrical dye-bath, the dyeing substrate was initially wetted by the foam, and dye molecule transported by the foam film was adsorbed on the substrate-liquid interface, and it was uniformly diffused into the substrate under the appropriate dyeing condition; $3 \mathrm{l} / \mathrm{min}$ of the air flow rate, 2.0 to $2.5 \%$ region of acetic acid content, at $80^{\circ} \mathrm{C}$, and for $30 \mathrm{~min}$.

\section{References}

1) J, Keaton and B. Glover, J. Soc. Dyers Colour., 101, 86 (1985)

2) G. H. Lister, J. Soc. Dyers Colour., 88, 9 (1972)

3) Sandoz Co., Ltd., Senshoku Kogyo, 28, 188 (1980)

4) F. Reinert and W. Kothe, Melliand Textilber. Int., 63, 138 (1982)

5) M. Kobayashi and M. Minagawa, Annual Rep. of Sci. of Living, Osaka City Univ., 35, 85 (1987)

6) T. Kariyone, "Kaimenkasseizaino Seishitsuto sono Ohyo", Saiwai, Tokyo, p. 148-151 (1980)

7) Am. Soc, for Testing and Materials, Method D1173-53, Philadelphia, (1953); JIS K33621970

8) J. J. Bikerman, "Foams", Springer-Verlag, Hidelberg, New York, p. 76-83 (1973)

9) Yukigosei Kagaku Kyokai, "Senryo Binran", Maruzen, Tokyo, p. 84-87 (1975)

10) L. Peters, J. Soc. Dyers Colour., 71, 174 (1955)

\section{泡沫染色法の羊毛繊維布一酸性染料系への応用}

\section{大阪市立大学生活科学部 小林政司，皆川 基}

近年染色分野では省エネルギ一，省凟源，節水，環境 保全なよ゙のあらゆる角度から染色工程の合理化が強く要 求されているため, むら染めを生じないきわどい条件で 染色時間の短縮や浴比の低减などがはかられている。 1971 年以来, 吸尽染色に扣りる水の大部分を空気に置き 換えた気泡による染色加発表されているが，気泡浴の安 定性の問題や湿潤性の変動など多くの問題をかかえてい B。

そこで著者らは、染色工程におりる節水および省エネ ルギー化, 染色廃液による環境污染の軽隇, 織維布の損 智劣化の防上，染色堅乃う性の向上などを目的として， 泡沫を利用した機械作用の著しく小さい，超低浴比，分 離型泡沫染色茭置を試作し，本報では羊毛一酸性染料系 で行った各染色条件上染色性の関係並びに総括的な泡沫 物性の指標として泡倍率，バルク染液の起泡性，泡安定 度, 泡膜中の染料濃度を取り上代実験を行うと共に液浸 型の染色との比較検討も併せて行い，次の結果を得た。

1) 本抱沫染色装置では染色時の浴比を1:3まで低下 させることができ，このとき高浴比に比し高い染着量が
得られた。

2）泡沫染色の起泡剂として用いる非イオン界面活生 剂としては，アルキル鎖長が長くエチレンオキサイドの 付加モル数の比較的小さいむのすなわち HLB の小さい 手のが適するが，染色時の起泡性，泡沫安定性老考慮す るよ量点が染色温度よりあ高いものでなりればならない。

3）泡沫染色においては，泡膜中の染料濃度がバルク 液中の染料濃度に比し小さくなる傾向にあるが，染料濃 度の補正により液浸型の染色上活涪同等の染色性を得る ととが可能である。

4）酸性染料による羊毛布の泡沫染色においては，泡 膜中に染料を保持する泡沫でまず布を湿閏させ，維維の 内部表面までを含めた染液緎維界面において泡膜中の染 料分子を吸着させ，最終的には適正条件すなわち空気流 量 $3 \mathrm{l} / \mathrm{min}$ ，酢酸助剂濃度 $2.0 \sim 2.5 \%$ o.w.f.，染色温度 $80^{\circ} \mathrm{C}$ ，染色時間 30 分間で織維表面に吸着させた染料分 子を繊維基質の内部へ均一に抎散移動させることが可能 であり，效率的なしかむむらのない染色が得られる。 